\title{
Trajectories in higher education: ProUni in focus ${ }^{1}$
}

Vera Lucia Felicetti a Alberto F. Cabrera ${ }^{b}$

\section{Abstract}

Trajectories in higher education and the University for All Program (ProUni) are the central theme of this paper. The research question was: To what extent were some factors experienced during university difficulties in the academic trajectory of ProUni and non-ProUni graduates? The approach was quantitative with an explanatory goal. Descriptive and inferential statistics were used in the data analysis. The research subjects were 197 higher education graduates from a Southern Brazil nonprofit institution who entered in 2005. 57 were ProUni scholarship holders and 140 were non-ProUni. Results indicate that the highest percentage of graduates who worked during college were not scholarship holders. A T-test was performed after creating the scales for external $(p=0.19)$ and internal $(\mathrm{p}=0.66)$ factors, indicating that in both factors there was no statistically significant difference between being a ProUni scholarship holder or not and the difficulties presented during their academic trajectory. Results indicate the need for studies involving the set of higher education graduates in order to better understand the difficulties faced by both groups of students in their academic trajectories.

Keywords: Higher education. Trajectories. Graduates. ProUni.

\section{Introduction}

Regarding Principles and Purposes of National Education, the National Education Guidelines and Framework Law (LDBEN ${ }^{2}$ ), Law no. 9,394 of December 20th, 1996 recommends, in Article 43, section II, that the goal of higher education is to

\footnotetext{
a Centro Universitário La Salle. Canoas, Rio Grande do Sul, Brasil.

b Maryland University. College Park, EUA.

1 This article is the result of a research project financed by the Conselho Nacional de Desenvolvimento Científico e Tecnológico - CNPq (National Council for Scientific and Technological Development-CNPq), Public Call MCTI/CNPq no. 14/2013/Universal.

2 Lei de Diretrizes e Bases da Educação Nacional - LDBEN.
}

Recebido em: 16 jun. 2016

Aceito em: 22 nov. 2016 
educate students in different areas of knowledge, qualifying them for placement in professional sectors as well as to participate in the development of society (BRASIL, 1996). Access and retention inherently precede higher-level education. With regard to access, this is a problem that has dragged on over the years and has been the subject of debates, both in politics and in education. Meanwhile, as political and educational debates carry on, government programs have grown, providing access to higher education.

Among the government programs aimed at access to higher education, we highlight here the University for All Program - ProUni ${ }^{3}$. This program is mainly focused on providing access to university to a portion of population that, without access programs, would not have a chance to enter higher education let alone complete it, especially the population with weaker "initial characteristics". They have been identified by Roemer (1998) as gender, age, race/ethnicity, disabilities, and family or socioeconomic status, which correspond to difficulties or barriers that are inherent to a person's being.

Although access is the central objective of ProUni, countless criticisms have been made regarding student retention through this program (CASTELLAIN, 2008; GASPAR, 2012; GUERRA, 2009; LIMA, 2008; SOARES, 2009; VALLE, 2009). Retention in Brazilian higher education is a troubling issue, given the high dropout rate, whether in public, non-profit or private institutions (GAIOSO, 2005; LIMA, 2006; BAGGI; LOPES, 2011). Studies by Felicetti $(2011 ; 2014 a)$ indicate dropouts at this level of education by both students who are non-ProUni scholarship holders and scholarship holders, though to a lesser extent in the latter group.

Staying at university until completion is a challenge not only for students but also for universities, which need to develop student support programs in order to keep them in the program, to succeed in it, and graduate (GOMES; FELICETTI, 2015). In this sense, to recognize and understand what happens to students during their trajectory at university becomes a major factor for their retention. Studying students' academic trajectories highlights the difficulties they face, indicating aspects to be improved, created or changed in the student environment (FELICETTI, 2014b; VITELLI, 2012).

\footnotetext{
3 The University for All Program (ProUni), created in 2004 and established by Law no. 11,096, January, 13, 2005 , is aimed at providing scholarships, full or partial, to Brazilians with no degree, for them to study in private higher education institutions, either for-profit or non-profit. According to Art.1, §§ 1 and 2 of Law no. 11,096, full scholarships are granted to Brazilians with a per capita monthly household income that does not exceed the amount of one (1) and $1 / 2$ (half) minimum wages. For partial scholarships ( $50 \%$ or $25 \%$ ), the monthly per capita family income must not exceed the amount of three (3) minimum wages, according to criteria set by the Ministry of Education (BRASIL, 2005).
} 
Given the higher education, trajectory and ProUni triad, this article presents the following research question: To what extent were factors experienced during the university program difficulties in the academic trajectory of ProUni and non-ProUni graduates? The answers to this question correspond to the results of the second ${ }^{4}$ part of the analyses carried out with the database, referring to the responses by the higher education graduates who enrolled in a nonprofit higher education institution in Rio Grande do Sul in 2005.

Following this article, we present a brief theoretical background on the subject of trajectories/retention in higher education, followed by the methodology, data analysis, discussion and conclusions.

\section{Theoretical contribution}

The University for All Program is considered by many authors to be a program that guarantees access to higher education but does not guarantee retention, due to various difficulties faced by scholarship holders during their academic trajectory, whether they are social, economic or cognitive (FERREIRA, 2011; MARQUES, 2010; PEREIRA FILHO, 2011; ROCHA, 2008; SENA, 2011).

Studies involving ProUni emphasize the need to develop a quality public basic education, as a collaborating factor in good student performance in higher education institutions (HEI), and by extension, retention (COUTO, 2008; NEVES, 2011; SIMÕES, 2011). Accordingly, Zago (2006) notes difficulties faced by students from a federal university, graduates of public basic education, with regard to a discrepancy in the basic courses. Thus, there is a need for public policies to support and complement the program, including a quality basic education (COUTO 2008; MELLO, 2007; NEVES, 2011; SILVA, 2006; SOARES, 2009).

The academic performance of ProUni scholarship holders has been pointed out in several studies as being good, even though they come from public basic education, thus showing an effort and dedication to overcome the barriers imposed by a public education considered to be deficient (ALMEIDA, 2009; ALVES, 2008). Alvarenga et al. (2012) also identified a lack of prerequisites with students from a public university, graduates of public schools. The ProUni scholarship effort has been pointed out as a key aspect to getting good grades and not losing the scholarship (ESTÁCIA, 2009; FELICETTI, 2011; MONGIN, 2010; ROCHA, 2008; SENA, 2011). In many cases, a scholarship holder can lose the scholarship

This article is part of a project entitled "ProUni and non-ProUni scholarship holders entering higher education in 2005 in an HEl: where are the graduates and how are they?". 
due to poor grades and may drop out of higher education. Although there are scholarship holders who have dropped out, dropout percentages in relation to non-scholarship holders are lower (FELICETTI; FOSSATTI, 2014; PINTO, 2010). Getting a ProUni scholarship and keeping it until graduation is considered a meritocracy (FELICETTI, 2011).

Among several difficulties found in the academic trajectories of ProUni students, the most frequent one was financial difficulty (ALVES, 2008; ALMEIDA, 2009; ESTÁCIA, 2009; FACEIRA 2009; MARQUES, 2010; PEREIRA FILHO, 2011; PINTO, 2010; ROCHA, 2008; SANTOS, 2011; SIMÕES, 2011; SOUZA, 2011). Pinto (2010) claims, in the ProUni scholarship holder report, that scholarship holders believe that their non-scholarship holder colleagues also have financial difficulties.

Difficulties pertaining to the program and the university (FELICETTI, 2011; NONATO, 2012), as well as adapting to academic life, to a new city, in the case of students who had to move to another region or state to study, result in an adaptation of customs and habits. This is also part of the academic trajectory, making retention in the HEI difficult (ESTÁCIA, 2009; SANTOS, 2011). Another obstacle or difficulty found in the college trajectory was the combination of work with studies. Due to the necessary supply of food, transportation, materials such as books, copies, among others, many needed to work during the undergraduate program (ESTÁCIA, 2009; FACEIRA, 2009; MOGIN, 2010; PEREIRA FILHO, 2011; ROCHA, 2008).

Support by the HEI for students via welcome programs, monitoring, level assessment, socialization and interaction among students and teachers are contributing factors to retention in college (ESTÁCIA, 2009; KRAMES, 2010; ROCHA, 2008). When level assessment and support for improvements in the teaching and learning process are offered at the HEI, it allows students to get better results in their learning, thus leading to success in the course and in the program until graduation (BREGÃO; FELICETTI, 2015). Family support strengthens student retention and encourages them to complete the program (ESTÁCIA, 2009; ROCHA, 2008).

At the international level, one of the major references on the subject of retention in higher education is Vincent Tinto ${ }^{5}$. His studies revolve around strategies to reduce dropouts and increase retention. According to Tinto $(1975 ; 1987 ; 1993)$, dropouts are related to actions by both the students and the educational institution, especially regarding the students' interactions with their colleagues, teachers

\footnotetext{
${ }^{5}$ Emeritus Professor at Syracuse University (USA), PhD in Sociology and Education from Chicago University.
} 
and other institutional members. Institutional strategies, such as facilitating student integration to the university environment, promoting opportunities for interactions between colleagues and teachers, and creating knowledge level assessment resources, contribute to staying at university. In other words, students' social and academic integration is essential to their retention at college (RODRIGUEZ et al., 2013). Pedagogical and psychological support in the academic trajectory also contributes to retention at the HEI. The support for changing majors also contributes to retention and completion (PARRA et al., 2013; REGUEYRA, 2013).

Studies involving "non-traditional" students, those with weaker "initial characteristics," also indicate the need for institutional programs aimed at improving student integration, as well as providing pedagogical tools to teachers, so that they can better cope with the differences presented in the educational context (BEAN; METZNER, 1985).

Studies by Oloriz and Fernandes (2013) indicate the type of basic education school as an influencing factor in retention. Maintaining relationships with family and friends prior to attending university also constitutes support for student success and, by extension, university retention and completion (CABRERA et al., 1992a; 1992b; 1993; 2015).

Organizational changes, the higher education organization system, assessment and financing are also aspects related to retention in higher education (DE VRIES, 2011). Aspects such as good class attendance, incoming age and job activities during the undergraduate program are also intervening factors in retention in college (FIORI; RAMÍREZ, 2013).

Considering that the purpose of higher education is to educate students in different fields of knowledge, studying student retention/trajectories in higher education from different perspectives and topics, as shown above, constitutes a relevant factor in order to better outline trajectories at university.

Accordingly, this work presents a study involving both graduates of higher education who were ProUni scholarship holders and those who were not.

\section{Methodology}

The methodological approach of this study was quantitative in nature with an explanatory goal and intended to answer questions on aspects that 
pervaded the academic trajectories of the subjects invited to participate in this research.

The nature of the questions included in the research instrument justifies the use of a quantitative approach, since the purpose of these questions was to contribute and increase the understanding of the reality surrounding the academic trajectories of higher education graduates. These questions involved past facts, assuming, according to Silva and Menezes (2001), an ex post facto form of research. For Kerlinger (1984), ex post facto studies try to explain or understand aspects involving the variables studied, allowing new studies to emerge. We question here issues related to the academic career of the graduates who participated in this study. These graduates are from a non-profit higher education institution in Rio Grande do Sul (Brazil), entering in 2005 in the various university programs and graduated in June 2014, when this research study began. 3,967 students entered this institution in 2005, of which 1,473 (37.13\%) had graduated in June 2014.

The graduate students' contact information, such as e-mails and phone numbers, had been provided by the institution. All ethical standards of confidentiality were observed and respect for the participants maintained. Of the 1,473 graduates, $822^{6}(55.80 \%)$ could not be contacted, thus there were $651(44.2 \%)$ candidates left to answer the questionnaire. Of the 651 potential participants, $186(28.57 \%)$ had no email registered at the HEI, being contacted initially by phone and invited to answer the research instrument via email. From the initial contacts by phone, 75 (40.32\%) provided their e-mails and answered the instrument. Among the 465 (71.43\%) with valid e-mails provided by the HEI, $122(26.24 \%)$ answered. Thus, there was a total of 197 answered questionnaires $(30.28 \%$ of the 651 contacted). After exhausting all contact possibilities, all phone calls and (re)sending of e-mails had been complete, which took place from August 2014 to March 2015. For Marconi and Lakatos (2009), the average number of responses sent via e-mail is around $25.00 \%$, with $30.28 \%$ being above the expected average.

The survey questionnaire was generated in the Google Drive program, which provided a link for each generated instrument. The link was associated to the code sent to the graduates with an invitation letter. This association was necessary to confirm whether the respondent had sent the completed instrument more than once, which did not happen in this investigation. This code also allowed the

\footnotetext{
6 Those with invalid phones or e-mails and those with no phones or e-mails.
} 
researchers to control who had answered, in order not to repeat the e-mails sent and enabling phone contacts to those who had not answered.

The research instrument questions included aspects regarding who paid for college, whether graduates worked during the academic trajectory or not, whether work was a difficulty or not and whether or not there were financial difficulties, or a lack of material resources such as books, computer, internet at home, etc. We also asked whether the distance between the school and home or work was a difficulty, whether they had difficulties interacting with colleagues inside and outside of the classroom, whether there were learning difficulties due to a lack of prerequisites coming from basic education, and finally, whether they faced discrimination. In addition to the questions related to aspects that permeated the academic trajectory, the research instrument had questions of a socio-demographic nature, such as gender, age, race/ethnicity, and whether they were a ProUni scholarship holder or not.

The responses were organized in an Excel worksheet. Then, the data were imported to Stata/IC13.1, in order to perform the statistical and inferential analyses relevant to this study, following Acock (2014). Values given for responses involved a degree of agreement on a Likert scale and were assigned inversely, since they were negative responses, thus resulting in the following: strongly disagree was assigned 5; partially disagree, 4; neither agree nor disagree, 3; partially agree, 2 and strongly agree, 1 . These assignments were necessary in order to calculate the average and standard deviation. Thus, 5 was considered a maximum average in each group analyzed.

The analysis performed compared graduates who were ProUni scholarship holders with those who were not. A $\chi 2$ (chi-square) was calculated to test the association between being ProUni scholarship holders or not, having worked during college and who paid for college. A factorial analysis was used to examine the contribution of each component (question), in order to group the latent variables according to their degree of internal consistency. The internal consistency of the degree of reliability was classified into 5 Cronbach Alpha scales, distributed as follows: very low $(\alpha \leq 0.30)$, low $(0.30<\alpha \leq 0.60)$, moderate $(0.60<\alpha \leq 0.75)$, high $(0.75<\alpha \leq 0.90)$ and very high $(\alpha>0.90)$ (CRONBACH; SHAVELSON, 2004; FREITAS; RODRIGUES, 2005). After identifying the factors and creating the scales involving external factors (financial_dif + resources_dif $/ 2$ ) and internal factors (interaction_dif_in + interaction_dif_out + prejudice_dif) $/ 3$ ), the t-test was used to test the possible differences in factor averages between both ProUni and non-ProUni groups. The significance levels smaller than 5\% $(\mathrm{p}<0.05)$ 
were considered significant and values between $5 \%$ and $10 \%(0.05$ and 0.1$)$ were considered indicative of significance (BÓS, 2012).

\section{Data analysis}

197 respondents were represented by $81(41.12 \%)$ male graduates and $116(58.88 \%)$ female graduates. Regarding age, most were under 25 upon entering university in 2005, totaling $134(68.02 \%)$.

Table 1 contains data about who worked during college. As can be seen, most of the respondents, whether ProUni students or not, worked during this academic period. Of the 140 graduates who were not ProUni scholarship holders, $119(85.00 \%)$ worked during college, and among the 57 scholarship holders, $46(80.70 \%)$ worked. Although there was no statistically significant relationship between the graduate groups and the variable worked during college, $p=0.458$, we can see that the highest graduate percentage of those who did not work during college corresponds to the scholarship holders of the program.

As for the question regarding college payment, the answers are in Table 2. We can see that among the non-scholarship holders the highest percentage (42.86\%) corresponds to the family paying for college, followed by the student himself (38.57\%). This makes it clear that students need to work during college to pay for it. We can also see, according to the data presented in Table 2, that 26 graduates had another way to pay for college, 13 of them through the FIES Student Financing Program (Financiamento Estudantil - FIES), and the other 13 had another form of aid, which may be scholarships from the company where they worked.

There was a statistically significant relationship between the groups of graduates and the "college payment" variable, with $\mathrm{p}=0.0001$. The need to work during

Table 1. Worked during college.

\begin{tabular}{lccccc}
\hline \multirow{2}{*}{ Variable } & Factors & $\begin{array}{c}\text { Not } \\
\text { ProUni }\end{array}$ & ProUni & Total & $\begin{array}{c}\text { Association between } \\
\text { being ProUni or not }\end{array}$ \\
\cline { 3 - 6 } & & \multicolumn{5}{c}{ Fr. (\%) } & $\mathbf{X}^{2}, \mathbf{d f}$ \\
\hline $\begin{array}{l}\text { Worked during } \\
\text { college }\end{array}$ & No & $21(15.00)$ & $11(19.30)$ & $32(16.24)$ & 0.458 \\
Total & Yes & $119(85.00)$ & $46(80.70)$ & $165(83.76)$ & - \\
\hline
\end{tabular}

Source: Database composed of questionnaire responses (2015). 
college was observed in a similar proportion between the two groups interviewed, although their studies had been fully paid by the scholarship in the case of the ProUni group.

Table 3 presents the average for the variable "difficulties found during the academic trajectory" between ProUni and non-ProUni graduates. We also present in this Table the difference between averages for each type of difficulty, as well as the result of the t-test for significance of the differences of the averages between being ProUni or not. We note here that the smaller the average is, the greater the difficulty presented, and that the average among the responses corresponds to 3.0.

Table 2. Who paid for college.

\begin{tabular}{lccc}
\hline \multirow{2}{*}{ College payment } & Not ProUni & ProUni & $\begin{array}{c}\text { Association between } \\
\text { being ProUni or not }\end{array}$ \\
\cline { 2 - 4 } & \multicolumn{2}{c}{ Fr. (\%) } & $\mathbf{X}^{\mathbf{2}}$, df \\
\hline Yourself & $54(38.57)$ & 0 & \\
Your family & $60(42.86)$ & 0 & 0.0001 \\
ProUni scholarship holder & 0 & $57(100)$ & \\
FIES & $13(9.29)$ & 0 & \\
Other & $13(9.29)$ & 0 & \\
Total & $140(100)$ & $57(100)$ & \\
\hline
\end{tabular}

Source: Database composed of questionnaire responses (2015).

Table 3. Average of difficulties found during the academic trajectory.

\begin{tabular}{|c|c|c|c|c|}
\hline \multirow[t]{2}{*}{ Difficulties } & $\begin{array}{c}\text { Not } \\
\text { ProUni }\end{array}$ & ProUni & \multirow[t]{2}{*}{ Difference } & \multirow{2}{*}{$\begin{array}{c}\begin{array}{r}\text { Difference } \\
\text { significance }\end{array} \\
\mathbf{p}\end{array}$} \\
\hline & \multicolumn{2}{|c|}{ Mean } & & \\
\hline Working & 2.64 & 2.93 & -0.29 & 0.91 \\
\hline Financial & 2.22 & 2.44 & -0.21 & 0.85 \\
\hline Material resources & 2.89 & 2.35 & 0.53 & 0.01 \\
\hline Distance & 3.10 & 2.95 & 0.15 & 0.28 \\
\hline Interaction in classroom & 4.42 & 4.65 & -0.23 & 0.93 \\
\hline Interaction outside classroom & 4.39 & 4.54 & 0.15 & 0.16 \\
\hline Learning & 3.20 & 3.30 & -0.10 & 0.67 \\
\hline Discrimination & 4.57 & 4.35 & 0.22 & 0.08 \\
\hline
\end{tabular}

Source: Database composed of questionnaire responses (2015). 
As can be seen in Table 3, there was a statistically significant difference $(p=0.01)$ only for the averages for the difficulty with "material resources" (such as having a computer, internet access at home, books, etc.), and between being ProUni, which obtained a lower average (2.35), and not being ProUni. This proves that ProUni graduates would have had greater difficulty with material resources than their non-scholarship holder colleagues. The Discrimination difficulty presented a statistical difference indicating a significance of $p=0.08$, where the ProUni group again obtained a lower average (4.35), indicating greater difficulty with discrimination than their non-ProUni colleagues.

Although there was no significant difference in the averages of other kinds of difficulties between graduates, we observed that the non-ProUni graduates experienced greater financial difficulty than their ProUni colleagues. Moreover, in the working during college variable, the former group also had greater difficulties. That is, they had an average of 2.22 for financial difficulty, and 2.64 for the working during college difficulty. This can be explained by the fact that they have to pay for college, since $38.57 \%$ (see Table 2) of the non-scholarship holders were responsible for their monthly payments, as well as by the $85.00 \%$ (see Table 1 ) of non-scholarship holders who worked during college. Classroom interaction also showed to be a major difficulty among those who were not scholarship holders, although the average is close to 5 , corresponding to not strongly agreeing that this item had been a difficulty.

Table 4 contains questions that showed clusters, that is, difficulties presented during the academic trajectory grouped into external and internal factors. The questions that addressed distance between the school and home or work, learning due to the lack of prerequisites in basic education, and working during college as being difficulties during the college trajectory did not form clusters, so they are not presented in Table 4. As can be seen, the Cronbach's Alpha found for difficulties external to the college environment was 0.56, which is considered to be a low internal consistency $(0.30<\alpha \leq 0.60)$, according to Cronbach and Shavelson (2004). For internal difficulties, the Cronbach's Alpha was 0.73 , which, according to the same authors mentioned above, represents a moderate internal consistency $(0.60<\alpha \leq 0.75)$. Therefore, these two sets of questions need to be better formulated, including questions that are better organized in order to improve the internal consistency of the set of situations that may represent difficulties for students during their academic trajectory. 
Table 4. Contribution of the component factors in the Cronbach's Alpha test.

\begin{tabular}{|c|c|c|c|}
\hline \multirow{3}{*}{ Variables } & \multirow{3}{*}{$\begin{array}{c}\text { Satisfaction indicators } \\
\text { Factors }\end{array}$} & \multirow{2}{*}{\multicolumn{2}{|c|}{$\begin{array}{c}\text { Theoretical dimension } \\
\begin{array}{c}\text { Contribution of each } \\
\text { component factor in the test }\end{array}\end{array}$}} \\
\hline & & & \\
\hline & & $\begin{array}{c}\text { Internal } \\
\text { difficulties }\end{array}$ & $\begin{array}{c}\text { External } \\
\text { difficulties }\end{array}$ \\
\hline \multirow{5}{*}{ Difficulties } & Financial & 0.3906 & 0.7342 \\
\hline & Material resources & 0.5119 & 0.6478 \\
\hline & Interaction in classroom & 0.8015 & -0.4113 \\
\hline & $\begin{array}{l}\text { Interaction outside } \\
\text { classroom }\end{array}$ & 0.7921 & -0.3466 \\
\hline & Discrimination & 0.6906 & -0.0205 \\
\hline Internal consistency (Alpha) & - & 0.7300 & 0.5600 \\
\hline
\end{tabular}

Source: Database composed of questionnaire responses (2015).

A t-test was also carried out after creating the scale for the external $(p=0.19)$ and internal $(=0.66)$ factors, and in both, there was no statistically significant difference between having a ProUni scholarship or not, and the difficulties presented in their academic trajectory. This means that there is no significant difference between the responses of the two groups of graduates and the difficulties they faced. We can conclude that both groups had the same difficulties. This may show that students entering university via ProUni face the same problems as their non-scholarship holder colleagues, which indicates that both groups need the same support and services to be able to remain in college and graduate.

\section{Discussion}

The data related to working during college indicate that most participating graduates in this study worked during graduation. Moreover, if, on the one hand, the data pointed out that having a scholarship leads to graduation without needing to work, although with a percentage lower than $20.00 \%$, on the other hand, the same data show that most graduates who were not scholarship holders worked during their academic trajectory. This shows that working during college, in the Brazilian reality, is a characteristic that pervades higher education, whether the students are scholarship holders or not. This could not be any other way, since, from the number of private HEIs in Brazil, which account for over $80.00 \%$ of the existing HEIs in the country, most have higher enrollments in their evening classes. This is better evidenced in Table 5 . 
Table 5. Total enrollment summary in undergraduate programs in 2013 (Fr.(\%).

\begin{tabular}{lccc}
\hline Variable & Day & Evening & Total \\
\hline Public & $1,095,894(61.64)$ & $682,080(38.36)$ & $1,777,974$ \\
Private & $1,177,308(26.91)$ & $3,197,123(73.09)$ & $4,374,431$ \\
Brazil & $2,273,202(36.95)$ & $3,879,203(63.05)$ & $6,152,405$ \\
\hline
\end{tabular}

Source: INEP, 2013.

Table 5 shows that in 2013, of the 4,374,431 (71.10\% of the total in Brazil) enrollments in private institutions, $73.09 \%$ were in the evening, while 1,777,974 ( $28.90 \%$ of the total) in the public sector, $38.36 \%$ corresponded to evening classes. These data show that enrollments in evening courses in Brazil correspond to $63.05 \%$ of all enrolled students (INEP, 2013). Given this, Gonçalves (1987) states that it would be more natural to study before work, and only after completing the educational and professional development of the student, as a graduate, would they start to engage in professional activities. However, according to the author, "the reality of facts, emerging from the socio-economic conditions, often brings together the double status of employee and student within the working person" (GONÇALVES, 1987, p. 11). Thus, according to the author, instead of studying in order to work, one works in order to study.

The sentence posed by Gonçalves (1987) is clear, because graduates participating in this study indicated in their answers the need to work in order to remain at university, whether they were scholarship holders or not. For Barreiro and Terribili Filho (2007), the evening period is characterized by students who work during the day, in order to obtain financial resources to pay for college and stay there until graduation.

Working during the academic trajectory proved to be a greater difficulty among non-scholarship holders, though with a small difference between averages. This can be explained by the fact that, in addition to having to pay the costs of food, transportation and materials, they also had to pay the monthly college fee, while their scholarship holder colleagues did not. These research findings go beyond what has been found in studies by Estácia (2009), Faceira (2009), Felicetti (2011), Mongim (2010), Pereira Filho (2011), Rocha (2008) and Santos (2011), which studied only ProUni students who had to work to remain in college, as well as difficulties in reconciling work with studies.

Data from this study include scholarship holders and non-scholarship holders who graduated, making it clear that both groups have similar difficulties, which agrees 
with Pinto's study (2010), in which the ProUni students interviewed recognized that their non-scholarship holder colleagues also had the same difficulties in their academic trajectories. This shows that entering university, with or without a scholarship, is just the first step and is not the only obstacle to be overcome, but it does represent the beginning of an arduous trajectory for anyone who enters it.

In other words, the data presented here seem to make clear that providing opportunities for access to higher education to students seen as having weaker "initial characteristics" puts them on the same level of difficulties faced by their colleagues. In other words, being in college puts them in the same battle against difficulties of retention and completion at the university. These pieces of evidence are supported by the results of the t-test performed on the external $(p=0.19)$ and internal $(\mathrm{p}=0.66)$ factor scales, indicating that there was no statistically significant difference between having been a ProUni scholarship holder or not and the difficulties presented in their academic trajectory. These findings make two predictions: the first is that ProUni puts its incoming students on the same level as their non-ProUni colleagues regarding their retention/trajectory at university, and the second is the importance of welcome programs, support and the development of strategies in order to meet the needs of the student body to remain in college and get a quality education. This is the central point to be observed in processes regarding the evaluation of quality in higher education, because only a quality education is able to meet the requirements imposed on exercising a profession, when placed in society as university graduates.

\section{Conclusion}

There are countless factors that can contribute to student retention or dropouts at HEIs, with or without a scholarship, since, for both groups of incoming college students, it constitutes a new student context, unlike the one they experienced in basic education. Surely, this new reality will be permeated by new contexts or difficulties, such as study habits, commitment to studies, autonomy, work conditions and habits, financial conditions, residence, transportation, food, health, relationships with family, with their origins, with the student environment, the institutional environment, culture and leisure.

However, if, on the one hand, entering higher education represents a victory for students, especially for those taken as having "initial disadvantages", on the other hand, it will be a challenge to remain there and graduate, given all the intervening factors that pervade academic trajectories. Thus, investigating academic trajectories is relevant to understanding and to developing mechanisms capable of keeping students at university until graduation. However, investigating the trajectories of 
only graduates from public schools, those with "initial disadvantages", or only those who have or had a ProUni scholarship, gives only a partial view of what happens during the trajectories in this student universe, ignoring what happens to other students. Only by studying the entire student body and comparing their experiences, confrontations and difficulties is it possible to identify and/or understand all the problems surrounding the university context.

Only by studying the universe of all higher education graduates will it be possible to establish whether the University for All Program is meeting its goals, as well as making changes, not only in the social context of its scholarship holders or at university, but mostly in society as a whole. Thus, we will be evaluating the program's continuity or not, as well as its improvements or expansion.

Let us not be naive to take the study presented here as a definitive configuration of the difficulties faced by higher education graduates during their academic trajectory, but as a study that provides an overview of the academic trajectory of students from a nonprofit HEI in southern Brazil. This study indicates that facing the academic reality is a challenge to all incoming students, thus answering the main research question of this study: To what extent were some factors experienced during university difficulties in the academic trajectory between ProUni and non-ProUni graduates? It also pointed out the need and importance of studies involving higher education graduates.

Access and retention in higher education need to be understood as an interaction between the structural characteristics of society, such as current policies and feasible actions within the reach of universities, families and students (FELICETTI, 2011). 


\section{Percurso na educação superior: o ProUni em foco}

\section{Resumo}

O percurso na Educação Superior e o Programa Universidade para Todos (ProUni) correspondem a temática deste artigo. A questão de pesquisa foi: Em que medida alguns fatores experienciados durante a universidade foram dificuldades no percurso acadêmico entre egressos ProUni e não ProUni? A abordagem foi quantitativa com objetivo explicativo. Foi usada estatística descritiva e de inferência na análise dos dados. Os sujeitos da pesquisa foram 197 egressos da Educação Superior de uma Instituição Comunitária do Sul do Brasil que ingressaram em 2005, dos quais 57 eram bolsistas ProUni e 140 não bolsistas ProUni. Os resultados indicam que o maior percentual de egressos que trabalharam durante a graduação foi de não bolsistas. O T-test foi realizado após a criação das escalas para os fatores externos $(p=0,19)$ e internos $(p=0,66)$, indicando que em ambos os fatores não houve diferença estatisticamente significativa entre ter sido bolsista ProUni ou não e as dificuldades apresentadas no percurso acadêmico. Os resultados sinalizam a necessidade de estudos envolvendo o conjunto de egressos da Educação Superior de modo a melhor identificar as dificuldades enfrentadas por ambos os grupos de alunos no contexto acadêmico.

Palavras-chave: Educação superior. Percurso. Egresso. ProUni.

\section{Trayectoria en la educación superior: ProUni en la mira}

\section{Resumen}

La trayectoria en la Educación Superior y el Programa Universidad para Todos (ProUni) son los temas de este artículo. La pregunta de investigación es: ¿en qué medida algunos factores experimentados durante el proceso de formación en la universidad fueron dificultades en la ruta académica entre los egresados ProUni y no ProUni? El enfoque fue cuantitativo con objetivo explicativo. La estadística descriptiva e inferencial fueron utilizadas en el análisis de datos. Los sujetos del estudio fueron 197 egresados de la educación superior de una institución comunitaria en el sur de Brasil, que iniciaron sus estudios en 2005, de los cuales 57 eran becarios ProUni y 140 no becarios ProUni. Los resultados indican que el mayor porcentaje de egresados que trabajó durante la graduación fue de no becarios del ProUni. Se llevó a cabo la prueba T después de la creación de escalas para factores externos $(p=0,19)$ e internos $(p=0,66)$, lo que indicó que en ambos factores no hubo diferencia estadísticamente significativa entre haber sido becario ProUni o no y las dificultades que presentaron en el camino académico. Los resultados indican la necesidad de estudios con el conjunto de egresados de la educación superior con el fin de identificar mejor las dificultades que tienen ambos grupos de estudiantes en el contexto académico.

Palabras clave: Educación superior. Camino. Egresado. ProUni. 


\section{References}

ACOCK, A.C. A gentle introduction to stata. 4. ed. College Station: Stata, 2014.

ALMEIDA, M. A. Universidade para todos: o PROUNI na visão dos bolsistas de uma instituição de ensino superior. 2009. 121 f. Dissertação (Mestrado em Educação) - Pontifícia Universidade Católica de Campinas, Campinas, 2009.

ALVARENGA, C. F. et al. Desafios do ensino superior para estudantes de escola pública: um estudo na UFLA. RPCA, v. 6, n. 1, p. 55-71, jan/mar. 2012. http://doi.org/10.12712/rpca.v6i1.110

ALVES, A. G. O desempenho acadêmico dos alunos do Programa Universidade para Todos. 2008. 71 f. Dissertação (Mestrado em Educação) - Pontifícia Universidade Católica de São Paulo, São Paulo, 2008.

BAGGI, C. A. S.; LOPES, D. A. Evasão e avaliação institucional no ensino superior: uma discussão bibliográfica. Avaliação (Campinas), v. 16, n. 2, p. 355-74, jul. 2011. http://doi.org/10.1590/S1414-40772011000200007

BARREIRO, I. M. F.; TERRIBILI FILHO, A. Educação superior no período noturno no Brasil: políticas, intenções e omissões. Ensaio: Avaliação e Políticas Públicas em Educação, v. 15, n. 54, p. 81-102, jan./mar. 2007. http://doi.org/10.1590/S0104-40362007000100006

BEAN, J. P.; METZNER, B. S. A conceptual model of nontraditional undergraduate student attrition. Review of Educational Research, v. 55, n. 4, p. 485-540, 1985. http://doi.org/10.3102/00346543055004485

BÓS, A. J. G. EpiInfo sem mistérios: um manual prático. Porto Alegre: EDIPUCRS, 2012.

BRASIL. Lei No . 9.394, de 20 de dezembro de 1996. Estabelece as diretrizes e bases da educação nacional. Diário Oficial da União, 23 dez. 1996.

. Lei No 11.096, de 13 de janeiro de 2005. Institui o Programa

Universidade para Todos - PROUNI, regula a atuação de entidades beneficentes de assistência social no ensino superior; altera a Lei no 10.891, de 9 de julho de 2004, e dá outras providências. Diário Oficial da União, 14 jan. 2005

BREGÃO, T. C. C.; FELICETTI, V. L. Programa de nivelamento: contribuindo para a permanência e sucesso dos acadêmicos no UNILASALLE. In: CONGRESSO NACIONAL DE EDUCAÇÃO CATÓLICA, 3., 2015, Curitiba. Anais... Curitiba, PUCPR, 2015. 
CABRERA, A. F. et al. The convergence between two theories of college persistence. Journal of Higher Education, v. 63, n. 2, p. 143-64, Mar.-Apr 1992 b.

CABRERA, A. F.; NORA A. CASTAÑEDA, M. B. The role of finances in the persistence process: a structural model. Research in Higher Education, v. 33, n. 5, p. 571-93, Oct. 1992a.

. College persistence: the testing of an integrated model. Journal of Higher Education, v. 64, n. 2, p. 123-39, Jan. 1993.

CABRERA, A. F.; PEREZ, P. M.; LÓPEZ, L. F. Evolución de perspectivas en el estudio de la retención universitaria en los EEUU: bases conceptuales y puntos de inflexión. In: GAZO, P. F. (Ed.). Persistir con éxito en la universidad: de la investigación a la acción. Barcelona: Laertes, 2015. p. 15-40.

CASTELLAIN, F.O PROUNI como política pública de democratização da educação superior e realidade institucional: a experiência da PUC-Rio. 2008. 106 f. Dissertação (Mestrado em Educação) - Universidade Católica de Petrópolis, Petrópolis, 2008.

CRONBACH, L. J.; SHAVELSON, R. J. My current thoughts on coefficient alpha and successor procedures. Educational and Psychological Measurement, v. 64, n. 3, p. 391-418, June 2004. http://doi.org/10.1177/0013164404266386

COUTO, V. P. C. O acesso à educação superior na percepção de concluintes do ensino médio: um estudo de sua trajetória e aspirações. 2008. 108f. Disertação (Mestrado em Educação) - Universidade Católica de Brasília, Brasília, 2008.

DE VRIES, W. et al. ¿Desertores o decepcionados? Distintas causas para abandonar los estudios universitarios. Revista de la Educación Superior, v. 40, n. 160 , p. 29-49, oct./dic. 2011.

ESTÁCIA, M. A. T. Alunos do PROUNI da Universidade de Passo Fundo: trajetórias, percepções/sentimentos a aproveitamento acadêmico. 2009. $233 \mathrm{f}$. Tese (Doutorado em Educação) - Universidade Federal do Rio Grande do Sul, Porto Alegre, 2009.

FACEIRA, L. S. O ProUni como política pública em suas instâncias macroestruturais, meso-institucionais e microssociais: pesquisa sobre a sua implementação pelo MEC e por duas Universidades na Região Metropolitana do Rio. 2009. 286 f. Tese (Doutorado em Educação) — Pontifícia Universidade Católica do Rio de Janeiro, Rio de Janeiro, 2009. 
FELICETTI, V. L. Comprometimento do aluno ProUni: acesso, persistência e formação acadêmica. Revista Brasileira de Estudos Pedagógicos, v. 95, n. 241, p. 526-43, set./dez. 2014a. http://doi.org/10.1590/S2176-6681/301911955

. Comprometimento do estudante: um elo entre aprendizagem e inclusão social na qualidade da educação superior. 2011. $298 \mathrm{f}$. Tese (Doutorado em Educação) - Pontifícia Universidade do Rio Grande do Sul, Porto Alegre, 2011.

. Licenciados PROUNI: dificuldades no percurso acadêmico e resultados da formação. Revista Ibero-Americana de Educación, $\mathrm{n}^{\circ} .64 / 1$, p. $2-10$, jan. 2014 b.

FELICETTI, V.L.; FOSSATTI, P. Alunos ProUni e não ProUni nos cursos de licenciatura: evasão em foco. Educar em Revista, n. 51, p. 265-82, jan./mar. 2014.

FERREIRA, K.T. PROUNI: trajetórias. 2011. 166 f. Tese (Doutorado em Educação) - Universidade Federal de São Carlos, São Carlos, 2011.

FIORI, N.; RAMÍREZ, R. Análisis de las trayectorias y perfil de los estudiantes desafiliados en la Universidad de la República en el período 2007-2012. In: CONFERENCIA LATINOAMERICANA SOBRE EL ABANDONO EN LA EDUCACIÓN SUPERIOR, 3., 2013, México, DF. Anales... Madrid: E. U. I. T. de Telecomunicacion., 2013. p. 259-78.

FREITAS, A. L. P.; RODRIGUES, S. G. R. A avaliação da confiabilidade de questionários: uma análise utilizando o coeficiente Alfa de Cronbach. In: SIMPÓSIO DE ENGENHARIA DE PRODUÇÃO, 12. 2005, Bauru. Anais... Bauru: Unesp, 2005.

GAIOSO, N. P. L. A evasão discente na educação superior no Brasil: na perspectiva de alunos e dirigentes. 2005. 99 f. Dissertação (Mestrado em Educação) - Universidade Católica de Brasília, Brasília, DF, 2005.

GASPAR, D.C. O acesso ao ensino superior: um estudo sobre o ProUni. 2012. 111 f. Dissertação (Mestrado em Educação) — Instituto de Ciências Humanas e Filosofia, Universidade Federal Fluminense, Niterói, 2012.

GOMES, K. A.; FELICETTI, V. L. Programa de tutoría cálculo diferencial e integral i: éxito y permanencia. Espiral: Revista de Docencia e Investigación, v. 5, n. 1, p. 93-100, 2015. http://doi.org/10.15332/erdi.v5i1.1272 
GONÇALVES, E. O estudante no direito do trabalho. São Paulo: LTR, 1987.

GUERRA, L. C. B. O processo de criação do Programa Universidade para Todos - PROUNI. 2009. 229 f. Dissertação (Mestrado) - Universidade Federal do Rio Grande do Norte, Natal, 2009.

INSTITUTO NACIONAL DE ESTUDOS E PESQUISAS EDUCACIONAIS ANÍSIO TEIXEIRA - INEP. Sinopses estatísticas da educação superior - Graduação. Brasília, DF, 2013. Disponível em: <http://portal.inep. gov.br/superior-censosuperior-sinopse >. Acsso em: 18 jul. 2015.

KERLINGER, F. Foundations of behavioral research: educational and psychological inquiry. New York: Holt Rinehart, 1984.

KRAMES, I. P. Na trilha do PROUNI: implantação, acompanhamento e perspectivas em uma instituição de ensino superior de Santa Catarina. 2010. 130 f. Tese (Doutorado em Educação) - Pontifícia Universidade Católica de São Paulo, São Paulo, 2010.

LIMA, V. M.. Percepções de estudantes de primeiro periodo sobre o serviço educacional: análise empírica de uma IES privada na cidade do Rio de Janeiro. 2006. 145 f. Dissertação (Mestrado em Educação) — Faculdade de Economia e Finanças IBMEC, Rio de Janeiro, 2006.

LIMA, R. L. A. A. Cotas: uma política de inclusão. 2008. 150f. Dissertação (Mestrado em Serviço Social ) —Universidade Est. Paulista Júlio de Mesquita Filho, Franca, 2008.

MARCONI, M. A.; LAKATOS, E. M. Fundamentos de metodologia cientifica. São Paulo: Atlas, 2009.

MARQUES, E. P. S. O programa universidade para todos e a inserção de negros na educação superior: a experiência de duas Instituições de Educação Superior de Mato Grosso do Sul - 2005-2008. 2010. 249 f. Tese (Doutorado em Ciências Humanas) - Universidade Federal de São Carlos, São Carolos, 2010.

MELLO, C. M. Programa universidade para todos PROUNI: acesso ao Ensino Superior e qualificação: para quê? 2007143 f. Dissertação (Mestrado em Educação) - Universidade Tuiuti, Curitiba, 2007.

MONGIM, A. B. Título universitário e prestígio social: percursos sociais de estudantes beneficiários do ProUni. 2010. 176 f. Tese (Doutorado em Educação) - Universidade Federal Fluminense, Rio de Janeiro, 2010. 
NEVES, D. M. A permanência de bolsistas PROUNI no curso noturno de pedagogia do Centro Universitário do Norte-UNINORTE/LAUREATE-AM. 2011. 125 f. Dissertação (Mestrado em Serviço Social) — Pontifícia Universidade Católica do Ri de Janeiro, Rio de Janeiro, 2011.

NONATO, B. F. Sentidos da experiência universitária para jovens bolsistas do ProUni. 2012. 210 f. Dissertação (Mestrado em Educação ) -Universidade Federal de Minas Gerais, Belo Horizonte, 2012.

OLORIZ, M.G.; FERNANDEZ, J.M.. Relación entre las características del estudiante al momento de iniciar estudios superiores y el abandono en la Universidad Nacional de Luján durante el período 2000-2010. In: CONFERENCIA LATINOAMERICANA SOBRE EL ABANDONO EN LA EDUCACIÓN SUPERIOR, 3., 2013, México, DF. Anales... Madrid: E. U. I. T. de Telecomunicacion., 2013. p. 70-81.

PARRA, C. M. et al. Rendimiento académico de los estudiantes de primer semestre de pregrado de la facultad de ingeniería de la Universidad de Antioquia: cohorte 2012-2. In: CONFERENCIA LATINOAMERICANA SOBRE EL ABANDONO EN LA EDUCACIÓN SUPERIOR, 3., 2013, México, DF. Anales... Madrid: E. U. I. T. de Telecomunicacion., 2013. p. 306-12.

PEREIRA FILHO, E. S. Perfil de jovens universitários bolsistas do ProUni: um estudo de caso na Unisinos. 2011. $131 \mathrm{f}$. Tese (Doutorado em Ciências Sociais) - Universidade do Vale do Rio dos Sinos, Porto Alegre, 2011.

PINTO, M. L. M. Qualidade da Educação Superior: limites e possibilidades de uma política de inclusão. 2010. $201 \mathrm{f}$. Tese (Doutorado em Educação) - Universidade do Vale do Rio dos Sinos, RS. 2010.

REGUEYRA, M. G. E. Aprendizajes sobre la población estudiantil que no continúa y el derecho a la educación superior. In: CONFERENCIA LATINOAMERICANA SOBRE ELABANDONO EN LA EDUCACIÓN SUPERIOR, 3., 2013, México, DF. Anales... Madrid: E. U. I. T. de Telecomunicacion., 2013. p. 59-69.

ROCHA, M.A.M. Processo de inclusão ilusória: a condição do jovem bolsista universitário. 2008. 266 f. Tese (Doutorado em Educação) - Pontifícia Universidade Católica do Rio Grande do Sul, Porto Alegre, 2008.

RODRIGUEZ, M.A. et al. Población con riesgo de abandono universitario. Una aproximación desde la prevención. Universidad de Antioquia 2013. In: CONFERENCIA LATINOAMERICANA SOBRE EL ABANDONO EN LA EDUCACIÓN SUPERIOR, 3., 2013, México, DF. Anales... Madrid: E. U. I. T. de Telecomunicacion., 2013. p. 142-9. 
ROEMER, J. E. Equalizing opportunities (in one country) for human development. Washington, DC: Inter-American Development Bank, 1998. (Sustainable Development Department, Technical paper series, POV 106).

SANTOS, N. M. C. Educação e PROUNI: política de inclusão social na perspectiva transdisciplinar. 2011. $221 \mathrm{f}$. Tese (Doutorado em Educação) - Pontifícia Universidade Católica de São Paulo, São Paulo, 2011.

SENA, E. F. Estímulo, acesso, permanência e conclusão no ensino superior de alunos bolsistas do programa universidade para todos (PROUNI): contribuições para o enfrentamento do processo de inserção. 2011. $225 \mathrm{f}$. Tese (Doutorado em Educação) - Pontifícia Universidade Católica de São Paulo, São Paulo, 2011.

SILVA, E. L.; MENEZES, E. M. Metodologia da pesquisa e elaboração de dissertação. (3. ed.). Florianópolis: Laboratório de Ensino a Distância da UFSC, 2001.

SILVA, F. C. M. Políticas públicas de inclusão social e iniciativas de acessibilidade no Ensino Superior particular do Triângulo Mineiro: uma discussão das tendências na ótica de formadores de opinião. 2006. 139 f. Dissertação (Mestrado em Educação) — Universidade São Marcos, São Paulo, 2006.

SIMÕES, P. R. R. Programa Universidade para Todos (PROUNI): mudanças e possibilidades na vida dos sujeitos bolsistas. 2011. $166 \mathrm{f}$. Tese (Doutorado em Educação) - Pontifícia Universidade Católica de São Paulo, São Paulo, 2011.

SOARES, J. P. P. Programa Universidade para Todos (ProUni) e as políticas sociais: o caso do município de Campos dos Goytacazes. 2009. $153 \mathrm{f}$.

Dissertação (Mestrado em Políticas Sociais) - Universidade Estadual do Norte Fluminense Darcy Ribeiro, Campos dos Goytacazes, 2009.

SOUZA, L. E. R. A. O ProUni como política pública de ação afirmativa: uma análise do impacto sociocultural na trajetória de egressos, oriundos das camadas populares, do ProUni da PUC-MG. 2011. 113 f. Dissertação (Mestrado em Educação) —Pontifícia Universidade Católica de Minas Gerais, Belo Horizonte, 2011.

TINTO, V. Dropout from higher education: a theoretical synthesis of recent research. Review of Educational Research, v. 45, n. 1, p. 89-125, 1975.

Leaving college: rethinking the causes and cures of student attrition. Chicago: University of Chicago Press, 1987. 
TINTO, V. Reflexiones sobre el abandono de los estudios superiores. Perfiles Educativos, n. 62, p. 56-63, 1993.

VALLE, M. J. PROUNI: Política pública de acesso ao ensino superior ou privatização? 2009. 111 f. Dissertação (Mestrado em Educação) - Universidade Tuiuti do Paraná, Curitiba, 2009.

VITELLI, R. F. Evasão em cursos de graduação: fatores intervenientes no Fenômeno. In: CONFERENCIA LATINOAMERICANA SOBRE EL ABANDONO EN LA EDUCACIÓN SUPERIOR, 2., 2012, Medelin. Anales... Madrid: E. U. I. T. de Telecomunicacion., 2012. p. 49-60.

ZAGO, N. Do acesso à permanência no ensino superior: percursos de estudantes universitários de camadas populares. Revista Brasileira de Educação. v. 11, n. 32, p. 226-30, maio/ag. 2006.

\section{Informações dos autores}

Vera Lucia Felicetti: Doutora em Educação. Pós-graduada em Educação. Professora do Centro Universitário La Salle Canoas, Rio Grande do Sul, Brasil. Contato: vera. felicetti@unilasalle.edu.br

Alberto F. Cabrera: Doutor em Administração Educacional. Professor da Pós-graduação em Ensino Superior da Maryland University, EUA. Contato: cabreraf@umd.edu 